Westen K Shilaho

National Research

Foundation (NRF) Scarce

Skills Post-Doctoral

Research Fellow,

SARChI Chair: African

Diplomacy and Foreign

Policy, University of

Johannesburg.

wshilaho@gmail.com.

DOI: https://dx.doi.org/ 10.18820/24150509/

JCH41.v2.10

ISSN 0258-2422 (Print) ISSN 2415-0509 (Online)

Journal for

Contemporary History

2016 41(2):184-207

(C) UVIUFS

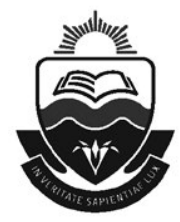

\section{THE PARADOX OF KENYA'S CONSTITUTIONAL REFORM PROCESS: WHAT FUTURE FOR CONSTITUTIONALISM? ${ }^{1}$}

\begin{abstract}
Kenya's protracted reform process and periodic electoral related violence is linked to predatory politics nestled in tribalism. Kenya's politicians' quest to capture the state for extractive purposes has rendered the reform process ethnically polarising and, since dialogue cannot prevail among Kenya's fragmented political class, the resort to violence becomes a means of making claims to the control of the state. This article argues that, although the promulgation of a Constitution in 2010 has the potential to address issues at the core of Kenya's post-colonial crisis, aspects such as inequitable resource distribution, ethnic and regional inequalities, disregard for the rule of law, impunity, a political elite characterised by tribalism and kleptocracy are posing a challenge to the implementation of the Constitution; thus placing the country's long term political stability in jeopardy.
\end{abstract}

Keywords: Kenya; state; tribalism; impunity; constitution; violence; justice.

Sleutelwoorde: Kenia; staat; stamstelsel; straffeloosheid; konstitusie; geweld; geregtigheid.

\section{INTRODUCTION}

Kenya's quest for reform, which fundamentally entails state restructuring, predated 1991 when the country returned to multiparty politics, following years of single party autocracy. It is a struggle that started during colonialism as Kenyans, and Africans in other parts of the continent, strove for self-governance and the right to manage their resources (Mbaku and Ihonvbere 2003:8). It continued during the 1960s after independence, owing to "the failure of the nationalist project" in the sense that as, "the new elites and nationalists appropriated the powers and privileges of the departing colonial officers, they initiated complex programs of exploitation, discrimination, marginalization of power and

1 The financial assistance of the NRF towards this research is acknowledged. The views expressed are the author's own. 
resources in urban areas, and intolerance" (Ihonvbere 2003a:40). This behaviour triggered a struggle by some among the ruling elite and those excluded from power for reform and state restructuring.

This article highlights the paradox that Kenya's kleptocratic ruling elite is expected to spearhead the reform process. Hence, the reform measures that were introduced following the 2007 post-election violence are more process oriented, than substantive. Kenya's reform struggle has been characterised by opportunism, and for this reason the concept of reform is invoked as a Trojan horse; a ruse to attain power and its attendant trappings. Once the objective is achieved, resistance against reform sets in; a move inspired by a sense of selfpreservation, entrenched neo-patrimonial politics and the overarching influence of tribalism in the country's political matrix. In 2002, a broad ethnic political grouping catapulted Mwai Kibaki to power, but in connivance with politicians mostly drawn from the Kikuyu tribe and the larger Mount Kenya region to which he belongs, he blocked reform in much the same way his predecessors, Jomo Kenyatta and Daniel Arap Moi, did throughout the one party era (Baregu 2010:33; Shilaho 2014:49). A single party mindset, manifested through exclusive politics, exploitation of the state for economic gain, impunity, systemic corruption and patronage, has torpedoed Kenya's attempts at transition to democracy (Ajulu 2008). Mbaku and Ihonvbere (2003:10) attribute this situation to the retention of the oppressive and exclusionary colonial state, where, "the new democrats have tried to use the same undemocratic exploitative, violent, corrupt, and exploitative political structures and methods of the past to govern in the new dispensation. The result has been an inability to truly democratize and build new foundations for inclusive and democratic polities."

This unreformed state works in the interest of the ruling elite and their cronies in a clientelist network that accrues financial and other material benefits to those in charge of the levers of power, or connected to them. In Kenya's case, this resulted in elite fragmentation and a heightened sense of ethnic consciousness that has polarised the country along ethnic lines. The consequences of this "no-holds-barred" political competition, often taking place in a polity devoid of agreeable rules of the game, were manifested in the ethnically divisive multiparty elections of 1992 and 1997, the 2005 constitutional referendum and the violently disputed 2007 presidential elections (Branch and Cheeseman 2009; Cheeseman 2008; Khadiagala 2008). More than any other event, the 2007 postelection violence unprecedentedly brought the idiom of reform to the centre of the country's political discourse. For the first time in the country's independence history, the link between predatory and corruption riddled politics, an unreformed state and impunity on the one hand, and politicised ethnicity as an overarching variable in contestation for power on the other, was stark (Mueller 2008). The far-reaching consequence of this cynical politics on Kenya's political stability is not in dispute. Big Man politics, the staple of the country's post colonial politics, 
compromised the principle of separation of powers and oversight institutions and made it impossible for the 2007 post-election disputes to be amicably and dispassionately resolved, leading to ethnic violence. Compounding the situation was the fact that the judiciary and the electoral body were devoid of integrity to command the respect and confidence of the opposition, which perceived these institutions as biased towards the incumbent (Baregu 2010:34-35; Shilaho 2013:94). The violence that ensued in the wake of the 2007 presidential elections was halted by the intervention of the international community through the African Union's Panel of Eminent African Personalities, whose mediation resulted in the cessation of the conflict, following a power sharing pact between Mwai Kibaki and Raila Odinga, as President and Prime Minister respectively (Khadiagala 2008). The power-sharing pact was also seen as a predatory "loot-sharing" conspiracy among political elite intent to share the spoils of power (Baregu 2010:33-34). Of significance is that the mediators drew up a road map for state restructuring, encompassing legal, institutional and constitutional reforms and reconciliation and healing which were identified as being at the core of Kenya's troubled postcolonial period, heightened under multiparty politics. The logic was that addressing these issues was a prerequisite to forestall further violence, especially during subsequent elections (Baregu 2010:33). However, the absence of political will has impeded enactment of the requisite reform and where it has been present, the government has hampered implementation.

The 2013 elections were held under the 2010 constitution but, like previous elections since the founding multiparty elections in 1992, were held in a climate of violence and lawlessness across the country (Human Rights Watch 2013). The performance of the electoral body during the elections left a lot to be desired, and would have plunged the country into violence had the opposition not petitioned the presidential results in court. There were multiple voter registers, malfunctioning of the electronic voter identification system (EVIDs) and of the results transmission system (RTS) (Shilaho 2013:58-59). In the wake of the elections, allegations of corruption, that implicated even the chairperson of the electoral body, emerged (Standard Digital 2014c; Business Daily 2014a; Business Daily 2014b). Thus Kenya's reform process has to contend with ethnic polarisation, disregard for the rule of law, cynicism among the political elite and, more insidiously, an old order mentality within the ruling kleptocracy. Competitive plural multiparty politics is yet to find traction, owing to a self-reproducing plutocracy anxious about a possible threat posed by a reformed state to entrenched economic and political interests.

The article begins with a focus on the history of the struggle for reform in Kenya, in an attempt to illuminate the protracted multiparty reform process, its twist and turns, and why the process has proved daunting and violence prone, resulting in damage to property, displacement, injury and deaths. It links blocked reform to the 2005 polarising referendum campaigns on a draft constitution and Kenya's near descent into civil war in $2007-2008$, following violently disputed 
elections. On a positive note, the violence accelerated the realisation of the 2010 Constitution. However, it did not inspire attitudinal change among the country's political elite. The caution is that democratic gains made since the advent of multiparty politics, whose high watermark is the 2010 Constitution, could be lost, unless predatory politics couched in tribalism, a surrogate concept for ethnicity, is addressed.

\section{THE CLAMOUR FOR CONSTITUTIONAL REFORM}

Kenya has made strides in its quest for state reformation. However, what is yet to find traction, is a sense of constitutionalism; that is, respect for the instrumentalities of governance that range from, "the constitution itself and other legally constructed documents that have been created to support it, to the structures and institutions that are established under their framework" (Onyango-Oloka 2001:2). Kenya has undergone reform since the autocratic single party dictatorship and, of now, most of the basic freedoms that were previously criminalised under the authoritarian one party state are recognised in the Constitution, although not respected by the Uhuru Kenyatta regime. An attempt to arrest an opposition leader, Raila Odinga, for exposing rampant corruption in the government is a case in point (The Star 2015b). The judiciary, although it has undergone some reform that saw some corrupt, tardy and unprofessional judges and magistrates sacked, is still weak, embroiled in corruption and still seen as an extension of the executive, as was the case during the one party state. The mighty, including Kenyatta, often defy its orders and verdicts (IVPR 2015; Shilaho 2013:93-102).

Kenya's parliament has failed dismally in its oversight role as a law-making arm of government, despite opposition representation. The House is divided along ethno-regional lines; a state of affairs that accounts for its propensity for insularity and corruption as opposed to business in the best interest of the country (Shilaho 2015:150; Daily Nation 2012b; Standard Digital 2015). In a survey by a research firm, Ipsos Synovate, in November 2015, most Kenyans sampled believed that the current parliament (2013-2017) is the worst in fighting corruption when compared to previous ones (The Star 2015a). These institutions and oversight bodies could, however, do better with executive leadership not mired in insularity, tribalism and other primordial interests. The substantive outcome of the quest for reform and the eradication of personal rule is enactment of the Constitution of 2010 which requires a culture of adherence to the rule of law to address impunity (Shilaho 2015:164).

Kenya's parliament was supposed to be independent of the executive, especially years into multiparty politics. However, it is afflicted by tribalism that makes a section of it executive leaning, corruption riddled, afflicted by ethnoregional fissures and, more significantly, inclined to predatory politics. Despite Kenyan MPs being among the world's highly paid, they do not pay tax, in 
defiance of the Constitution. Each backbencher earns US $\$ 9300$ a month, of which only US $\$ 2000$ is taxed (BBC News Africa 2011). In 2008, when the tenth parliament started, the total package of an MP rose to a staggering US $\$ 13090$ per month, or US $\$ 157080$ per year, second only to Nigeria in Africa, and one of the highest in the world. Besides, once they leave the House, Kenyan MPs get other emoluments and severance pay for each year served (Barkan and Matiangi 2009:57). Kenya's economy can ill afford such a huge wage bill, since it ranks among the most unequal societies in the world. ${ }^{2}$ Scholars referred to Kenya's bloated coalition government as "politics of collusion" in which previous political opponents united in pursuit of the state largesse, and with the aim of forming new political alliances in the run up to the 2013 elections (Cheeseman and Tendi 2010:207, 223). During the 2007 elections, Kenyatta and Ruto supported Kibaki and Odinga respectively, but forged an ethnic alliance cemented by the International Criminal Court (ICC) legal challenge during the 2013 elections.

The struggle for the realisation of comprehensive reform anchored in a progressive Constitution is at the centre of Kenya's struggle for not only multiparty democracy, but also plural politics. This, in essence, is what transition from a one-party dictatorial state to a rule based multiparty democracy is all about (Mutua 2009:99). Even before the height of the one party autocracy in the 1980s, politicians across the ethnic divide called for reform of the state to promote the rule of law, respect for basic freedoms, transparency and accountability (Mutunga 1996; Ochieng' 1995:98-99). There was apparent ethnic inclusivity among those opposed to single party dictatorship. However, some of those individuals were opportunists and tribal chauvinists, whose commitment to reform was exposed once former president Daniel Arap Moi left power in 2002 (Murungi 2000:72). Like Moi and Jomo Kenyatta before, they exploited tribalism to capture the state and to illicitly accumulate wealth. Mazrui (2001:22) argues that good governance must go beyond constitutionally limiting the powers of the government to include, "putting legal limits to the economic and commercial behaviour of the elite". Political opportunism stems from the fact that the post-colonial African state is unreformed and still exhibits attributes of the colonial state; chief among them being the centralisation of power, violence and exclusionary politics. It is on the basis of this logic that transitions in some African countries stalled, and even went horribly wrong by dissolving into civil strife (Mbaku and Ihonvbere 2003:11).

$2 \quad$ Kenya had disturbing statistics when it came to wealth distribution. Its richest citizens earned 56 times more than its poorest citizens and $10 \%$ of its citizens controlled $42 \%$ of the country's wealth. The poorest $10 \%$ controlled $0,76 \%$ of the country's wealth, making Kenya the tenth most unequal country in the world and the fifth in Africa (OMCT 2008:7). 


\section{CONCEPTUALISING CONSTITUTIONALISM}

From the perspective of the public-choice theory, "the design of the efficient constitutional compact is seen from the contractarian perspective, where the individual is the ultimate source of all value and each individual is treated equally" (Mbaku 2003:124). The concept of constitutionalism is used in this context to mean, "a process for developing, presenting, adopting, and utilizing a political compact that defines not only the power relations between political communities and constituencies, but also defines the rights, duties, and obligations of citizens in any society" (Ihonvbere 2003b:144). Kautz (1999 in Frohnen 2011:3) captures this understanding in a different wording, defining liberal constitutionalism as highly procedural and aimed at principally ensuring, "that no citizen be above the law; that the law be well settled and duly promulgated; that the forms of popular consent be respected; that the judges be known and impartial; that the judgments of the courts be fully and equitably enforced and so on". Mwesiga Baregu (2010:28) defines constitutionalism as, "a political culture that nurtures and sustains adherence to a Constitution as a social contract between the rulers and the ruled". From Henkin's point of view (1998:12 in Mbaku 2003:144), "[c]onstitutionalism implies also that the constitution cannot be suspended, circumvented or disregarded by political organs of government, and that it can be amended only by procedures appropriate to change of constitutional character and that give effect to the will of the people acting in constitutional mode". In all these definitions the centrality of people in a constitutional democracy is affirmed.

Institutionalised impunity in Kenya, however, ensures that errant politicians and other public officials are not held to account for breaches of the law that primarily include corruption, ethnic mobilisation, incitement to violence, hate speech, and ethnic stereotyping (Human Rights Watch 2011; Republic of Kenya 1992; Republic of Kenya 1999).

\section{THE IDEOLOGY OF TRIBALISM AS AN IMPEDIMENT TO REFORM}

Kenya's state is crippled by challenges that have defined its post-colonial period since independence in 1963 and that stem from piece meal, cosmetic and elite serving changes that centralised power, removed the doctrine of separation of powers, weakened institutions and fundamentally embedded divisive and exclusionary ethnic politics that threaten the country's social fabric (Shilaho 2012:245). Inextricably intertwined with impunity is the politicisation of tribalism. These twin challenges mutually reinforce each other, and in their presence "Big Man politics" thrives in the sense that the exercise of power revolves around an individual, the president, whose legitimacy springs from an ability to manipulate ethnic sentiment to attain power, as opposed to adherence to constitutionalism. 
Wanjala (1996:88) refers to this phenomenon as presidentialism; that is, "[...] a feature of African leadership that combines absolute power which African traditional rulers exercised over primitive society and the modern executive authority derived from deficient Lancaster House type constitutions".

Even before independence, a deeply entrenched culture of impunity finds traction in tribalism and vice versa (Ajulu 2008). Errant politicians and bureaucrats invoke ethnicity and seek sympathy from co-ethnics to avoid accountability; thus contestation for power is nestled in ethnicity. Although "tribe" and "tribalism" are controversial terms in social science they are commonly applied in Kenyans' discussion of their socio-economic and political challenges (Mafeje 1971:261). Berman (1998:306) observes that the word "tribalism" is associated with stigma; thus its denunciation in the Western social science discourse in which it is regarded as, "retrogressive and shameful, an unwelcome interruption of the pursuit of modernity", and the seemingly value free "ethnicity" is preferred. $\mathrm{He}$ further states that African politicians exploit and reify ethnic differences, because ethnicity buttresses patronage networks that are integral to power politics (Berman 1998:306). Kenyans do not talk about ethnicity, but prefer talking about tribalism that they experience daily, "in its many enabling capacities, incapacitating impact upon their hopes, and blocking of opportunities for whole communities. They use tribalism as a practical vocabulary of politics and social movements" (Atieno-Odhiambo 2002:230). In Kenya, tribalism is not an anachronism, but part of modernity. Tribalism is the default issue exploited for political mobilisation. The substantive question is competition for state control due to its resources among ethno-regional Big Men and cronies. Leys (1975) attributes the emergence of ethnic consciousness in Kenya to the moment when Kenyan ethnic groups began competing against one another as a result of a shift from the mode of production based on barter, to one of profit. Berman (1998:311) underscores the point by drawing a link between ethnicity and change in the mode of production, and the resultant impact on postcolonial politics.

\section{INEQUITABLE RESOURCE DISTRIBUTION AND POLARISED POLITICS}

Kenya's constitutional reform requires more than distribution of power among politicians. It is linked to the quest for equitable resource distribution among the citizens, irrespective of ethnic, political, regional and religious affiliation (Nyinguro and Otenyo 2007:16). Inequitable resource distribution and historical injustices, especially related to controversial land redistribution injustices in the immediate postcolonial period, are among the salient issues central to reform (Anderson and Lochery 2008:335-338). These inequities were caused and exacerbated by "Big Man politics" averse to the rule of law, and a Constitution devoid of checks and balances. The Independence Constitution, otherwise known as the 
Lancaster Constitution under which the country gained independence in 1963, was deliberately amended numerous times, first during the Jomo Kenyatta tenure (1963-1978) and then the Moi tenure (1978-2002), to remove all forms of oversight and to create a powerful president "above the law" (Wanjala 1996:91-92). The incumbent exploited this "mutilated" Constitution to exclude political opponents and the ethnic groups they belonged to from state resources (Khadiagala 2010:70). Despite its provision for democratic competitive politics and the separation of powers, including devolution of power to regions, the Lancaster Constitution was, in essence, colonial with, "a strong executive with imperial powers" (Khadiagala 2010: 67). However, Wanjala (1996:90) is of the view that, between 1964 and 1966, Kenya's presidential powers were, "fairly limited by inbuilt checks and balances".

There is a nexus between an elite centred constitution, economic and political exclusion along ethnic lines and tribalism that renders tribalism the overarching factor in disputed elections, endemic corruption, socio-economic inequalities and institutional atrophy. Ethnic groups excluded from state power and resources have comparatively lagged behind in access to, what is popularly known as, "development" that refers to public goods and economic opportunities, such as bureaucratic jobs weighed against "ruling" tribes. According to a government report entitled, Socio-Economic Atlas of Kenya, the Western, Coastal, Eastern and North Eastern regions are disproportionately affected by poverty as opposed to the Kikuyu inhabited region of Central Kenya and Kalenjin inhabited parts of Rift Valley (Standard Digital 2014b). Since independence in 1963, Kenya has had four presidents, of which three are Kikuyu and one a Kalenjin. This monopolisation of power and attendant economic inequality has precipitated resentment among members of the excluded ethnic groups against successive governments and feeds into tribal animosity (Daily Nation 2015).

\section{SELF-SERVING CONSTITUTIONAL AMENDMENTS AND INSTITUTIONALISED IMPUNITY}

Impunity in Kenya's body politic, like in many other African countries, is a colonial legacy, but institutionalised by post-colonial regimes (Onyango-Oloka 2001:4-5). Kenya's politicians are exempted from the consequences of the breach of law and other acts of moral turpitude, especially if they are part of the ruling kleptocracy or belong to the "ruling tribe". Impunity continues to undermine the state, since the definition of right or wrong is not predicated on constitutional interpretation, but on the ethnic affiliation of the accused politician or bureaucrat. It is now etched into the psyche of Kenya's ruling elite; a situation that is evidenced through rampant corruption, wastage of state resources, ethnic profiling, abuse of the state for partisan politics, and breaches of the constitution by Uhuru Kenyatta, as was the case during the previous regimes. These challenges are prominent in the central 
government and have cascaded into counties, devolved units that form the second tier of government, in place since the passage of the 2010 Constitution (Shilaho 2015). Therefore, there is a need to restructure the state and to anchor it in values, such as accountability, integrity, transparency, commitment to public good and respect for the rule of law.

Between 1963 and 1978, Parliament, at the behest of Jomo Kenyatta, effected 13 fundamental amendments to the Constitution to ensure that Kenyatta and close allies exclusively exercised political and economic dominance (Ochieng' 1995:94, 106-107). These changes maintained and even reinforced the oppressive character of the colonial state in that, "to some it began to look as though the old colonial power had simply transformed itself into one where Kenyatta was a new-style Governor and the Kikuyu had replaced the Europeans as the top dogs" (Ochieng' 1995:106). These arbitrary, but calculated amendments built a strong president and confined the control of the state in the hands of the incumbent and a handful of Kikuyu politicians; in effect ensuring that power was exercised not only informally, but also tribally. Kenya's presidents surround themselves with fellow tribesmen who constitute the inner circle, colloquially referred to as the Kitchen Cabinet, that profiteer from state largesse (Ajulu 2002:262; Ajulu 2008:34-40). Uhuru Kenyatta, in power since 2013, is Kikuyu and, like during the tenure of his father and that of his predecessor, Kibaki, is Kikuyu dominated (Standard Digital 2014a). This exclusive politics is inimical to stability, as is illustrated by ethnic violence during elections, since it reduces the presidency to the only political prize worth fighting for during elections.

A cavalier approach towards the Constitution has been part of Africa's postcolonial history. Hyden (2006:106) referred to Africa's period after independence until the end of the 1980s as one of opportunism in which, "the Constitution was prized more as a political instrument than as a statement of fundamental principles about how to conduct politics". Elite serving constitutional amendments have contributed to the challenges bedevilling Kenya's multiparty politics, such as elite fragmentation, politicised ethnicity, tribal violence over disputed elections, weak and dysfunctional institutions, disregard for the rule of law owing to the lingering traces of "Big Man politics", land conflicts and skewed resource distribution.

\section{CONSTITUTIONAL REFORM AND 2007-2008 POST- ELECTION VIOLENCE}

More than any other act of political instability in Kenya's independence period, the 2007-2008 post-election violence highlighted the risk that blocked reform and the absence of adherence to the spirit and letter of the law posed to the country as a viable nation. Kenya has experienced election related tribal clashes since 1991, but the 2007 post-election violence was unprecedented, since it almost 
plunged the country into civil war (Republic of Kenya 1992; Republic of Kenya 1999; Republic of Kenya 2008b). The fragility of an unreformed state manifested in dysfunctional institutions in a deeply ethnically divided society was exposed in the violently disputed 2007 presidential elections. The elections failed to produce an outright winner, amid accusations by the opposition against the incumbent, Mwai Kibaki, of theft of victory. Raila Odinga, the opposition presidential candidate, disputed the results, forcing his supporters to rise up in protest, whereupon security forces reacted with excessive force and extra judicially shot the protesters (Republic of Kenya 2008b). This dispute largely resulted from a disproportionately powerful presidency that had an adverse impact on the independence of oversight institutions, thus compromising the credibility of the elections. The electoral body, specifically its head, lacked impartiality, since it was composed of appointees without input from the opposition (Republic of Kenya 2008a).

In Kenya's a winner-takes-all political system, Odinga and allies almost lost out, and the possibility of being consigned to a political wilderness in which opportunities for rents and other perquisites that come with power were unavailable, was unsettling (Ghai 2008). An executive leaning judiciary contributed to the violence, as the aggrieved had no confidence in the courts to fairly adjudicate the matter since judges were presidential appointees, picked without vetting, and some on the basis of sharing ethnic affiliation with the incumbent (Republic of Kenya 2008a:31; Shilaho 2012). It was instructive that the Chief Justice, that hurriedly swore-in Kibaki at dusk, is Kikuyu. The dispute over the election results degenerated into tribal violence and, by the time it stopped, over 1 333 deaths had occurred and over 650000 people had been displaced (Republic of Kenya 2008b:345-352). Some semblance of political stability was restored through the signing of the National Accord on 28 February 2008 that undergirded power sharing, but the structural issues that precipitated the conflict remain intact; particularly historical land disputes in the Rift Valley, Coastal and other parts of the country. The power sharing was significant in the sense that it halted the violence and was supposed to provide a framework for substantive reform to avert conflict at a later stage.

\section{THE 2010 CONSTITUTIONAL DISPENSATION: STRIDES AND REVERSALS}

The promulgation of the Constitution in 2010 was a milestone in Kenya's independence history. The Constitution was meant to herald a new form of politics anchored in institutions, accountability, the rule of law and responsive leadership, and to do away with spoils politics in which personal enrichment and breach of law were the raison de'tre for occupying public office. It strove to do away with personal rule and personality centred politics propelled by the twin challenges of impunity and tribalism. One of the innovations of the Constitution was a clause on 
leadership and integrity. Specifically Chapter Six of the Constitution sets a high threshold of integrity for those aspiring for and occupying public office (Republic of Kenya 2010:51). Before then, individuals implicated in corruption, masterminds of the 1990s tribal violence and people of questionable integrity held public office as long as they were the president's allies. The clearance of Uhuru Kenyatta and William Ruto by the courts and electoral body to run for president and deputy president respectively in the 2013 elections, despite facing crimes against humanity at the ICC, dealt a blow to this piece of legislation.

The Constitution featured prominently during the 2007 election campaigns. Odinga's Orange Democratic Movement (ODM) party portrayed itself as the embodiment of change and dismissed Kibaki and his allies of the Party of National Unity (PNU) as reactionaries and, thus, hindrances to reform. The ODM comprised some seasoned opposition politicians, but the bulk of its politicians were entrenched in the rent seeking networks since the authoritarian one party state under Moi and were primarily drawn from the Kalenjin ethnic group in the Rift Valley Region, and thus were party to sabotage and frustration against reform under Moi (Barkan and Matiangi 2009).

Raila Odinga is arguably one of Kenya's foremost agitators for multiparty politics, respect for human rights and the rule of law for which he was detained during the authoritarian one party state under Moi. However, he is not immune from the pervasive ideology of tribalism that he has adroitly exploited to extend his supremacy beyond his Luo tribe and mobilise other disaffected and marginalised tribes in a bid to dislodge an equally tribally anchored kleptocraticplutocracy in power since 1963. Moreover, Odinga's democratic credentials are not flawless. The ODM party that he leads, has been characterised by shambolic, chaotic and flawed primaries since its inception in the wake of the 2005 referendum. Goons, affiliated to a faction of the ODM dubbed "Men in Black", forced the party to abandon party elections in February 2014 after invading the venue of the polls, overturned tables and election materials, and sent delegates scampering. Odinga handpicked ODM office bearers following the abortive elections (CapitalNews 2014).

As such, an attempt by the ODM to exclusively horde reform credentials, brand themselves as the vanguard of democratic tenets, and paint their opponents as anti-reformers cannot stand scrutiny. Thus, political parties are primarily ethnic aggregations competing for power. On the surface, electoral contests in 2007 and 2013 pitted the so-called reformers in the opposition against kleptocratic reactionaries. However, in actual sense there was no such dichotomy. The elections were about competition for power between ethno-regional political groupings in a political landscape devoid of competing visions for the country. Kenyan political elite, like most of their counterparts elsewhere in Africa, aspired to public office primarily for rent seeking, but not to transform the state and people's 
lives. Once in power, they criminally exploit the state for self-aggrandisement and easily discard manifestos that are drafted as a matter of formality.

The state and society nexus is so strong that Kenya's successive presidents have wantonly abused state resources for partisan politics to command the loyalty of the bureaucracy and of targeted ethnic constituencies. It creates an unstable polity, making it difficult to have a level political playing field for credible elections because of partisanship and personal rule politics, whereby state affairs are precariously linked to the president's idiosyncrasies and whims, as opposed to the rule of law and constitutionalism. Former UN Secretary General Kofi Annan, who led the Panel of Eminent African Personalities that brokered peace in 2008, observed that reforms hinged in the Constitution would ensure sustainable political stability in Kenya (Daily Nation 2010b). The logic was that Constitutional reform would provide a framework within which challenges at the core of the country's troubled post-colonial period would be addressed. Baregu (2010:33) was of the view that Kenya's coalition government was meant to restore the legitimacy of the Kenyan state by facilitating the enactment of a new constitutional order to address institutional weaknesses and other challenges that caused the post-election violence.

In the wake of the signing of the National Accord, the government put in place a number of reform measures, apparently to ensure long-term political stability. Several statutory bodies were set up to spearhead the intractable and reform process. Some of these bodies operated seamlessly, while others had to contend with the legacy of "Big Man politics" that has tended to compromise the impartiality of state institutions. The government set up the Committee of Experts (CoE) to lead in the quest for a new Constitution. Since there had been "peoplecentred" consultative processes through which Kenyans of various persuasions had made submissions regarding the kind of Constitution they desired, the body did not see the need to hold countrywide meetings once more to receive input from the populace, civil society and other interest groups. Except for the controversial executive and devolution clauses, Kenya had several Constitution drafts that were less polarising. These drafts provided the baseline for the 2010 Constitution. Care was taken to ensure that people's views were captured, unlike the Independence Constitution that, although legal, lacked legitimacy (Muigai 1996).

Kenyans voted for and approved the Constitution by $67,25 \%$ of the total votes cast on 4 August 2010 (Daily Nation 2010b). The highlight of the Constitution is that it provides for devolution of power and resources from the centre to 47 administrative units, called counties that form the second tier of government. The intention is to address the legacy of skewed resource allocation under the centralised state and the accompanying ethnic polarisation. The Constitution has an elaborate and progressive bill of rights covering socio-economic rights (Republic of Kenya 2010). However, under Uhuru Kenyatta Kenya is losing the 
gains made since the advent of multiparty politics and even risks degenerating into state repression, as was the case during the one party state.

Kenya suffered from numerous terror attacks by a Somali based AlShabaab terror group, following the deployment of its soldiers to Somalia in pursuit of terrorists in 2011. In reaction, Kenyatta assented to a controversial draconian Security Laws Amendment Bill 2014 under the guise of creating a legal framework for the fight against terror. Human rights groups and the opposition opposed the law, arguing that it was unconstitutional and flies in the face of the bill of rights. The bill affected 22 laws of Kenya without recourse to a referendum as stipulated in the Constitution (Republic of Kenya 2014). The opposition alliance, Coalition for Reforms and Democracy (CORD), challenged the law in court and had a reprieve when certain sections were suspended. Constant vigilance is needed from civil society, individual citizens and the opposition lest the country recedes into antidemocratic behaviour.

What distinguishes the 2010 Constitution from the previous one is that the drafters were sensitive to the interests of the commonality of the people, and so it is not a rigidly power based document only relevant to the political elite. Before, politicians invoked the Constitution in so far as power and distribution of the same among themselves was concerned. Socio-economic rights were peripheral within the grand scheme of things. Despite the Constitution being progressive, it is argued that the absence of a culture of accountability and political will stifle its implementation, ensuring that room remains for political activity along tribal lines. Endemic corruption undermines devolution the same way rampant corruption has corroded the national government (Shilaho 2015:164-168). Although the Constitution envisages a police service under civilian oversight, reform of the police has stalled and the Kenya police and other security forces continue to be implicated in gross human rights violations, such as extrajudicial killings, torture and forced disappearances of suspects, such as those suspected of involvement in terrorism (Al Jazeera 2014; KNCHR 2008).

\section{THE ILLUSION OF CHANGE IN KENYA}

The election of Uhuru Kenyatta and William Ruto, as president and deputy respectively, under the "alliance of the accused" during the 2013 elections, was a set back against the rule of law in the light of the egregious charges facing both of them at the ICC at the time. The insistence by the two to run for president on a joint ticket, despite being indictees, heightened the stakes. Two weeks before the 2013 elections, the High Court cleared Kenyatta and Ruto to contest for president and deputy president respectively, despite facing crimes against humanity charges asserting that, "[t]hey are innocent until proved guilty" (The Guardian 2013). Based on the integrity that the Constitution is expected to instil in the country's body politic, the mere fact that the two could run for, and 
controversially win the presidency, dented the struggle for reform and the rule of law in Kenya (Shilaho 2013:93-102).

The coalition government, formed in the wake of the 2007-2008 postelection violence and expected to set up mechanisms for reform, proved disastrous. It was a drain on the taxpayer, because it was bloated, mired in corruption and divided along ethno-regional lines. Some of the mega corruption scandals that defined it included the "Maize scandal", the "Triton oil scandal", and scandals at the Central Bank. Cabinet ministers and bureaucrats adversely implicated went scot free, due to the need to preserve political alliances rather than observe the rule of law (Shilaho 2012).

\section{THE 2010 CONSTITUTION: THE HURDLES}

The implementation of the 2010 Constitution through the enactment of the relevant Acts of Parliament and the vetting of personnel for positions in various arms of government, presented a challenge. Parliament enacted Acts inconsistent with the spirit, ethos and philosophy of the Constitution. An example was the watering down of the Leadership and Integrity Act that allowed Kenyatta and Ruto and other people of questionable credibility to occupy public office. The Political Parties Act was watered down to retain party hopping during primaries. It became almost impossible to regulate political parties and to inculcate internal democracy. Overall, breaches of the Constitution are meant to preserve the old order of centralised power and unaccountable leadership (Daily Nation 2012a; Shilaho 2015:174).

There were attempts to recruit people into public office on the basis of meritocracy, credibility and competence as part of the reform process. The vetting process has had mixed results. In some instances, meritocracy has prevailed, but in others recruitment and vetting of nominees to public office were marred by ethnic and regional politics. Parliament and other bodies gauged the suitability of candidates through the lens of ethno-regional politics and party affiliation. It led to candidates of questionable integrity and qualification being appointed. A case in point is the appointment of the Director of Public Prosecutions, Keriako Tobiko. He was among those opposed to reform, as evidenced by his conduct as a member of the Constitution of Kenya Review Commission (CKRC) that tried to write a new Constitution, but failed due to frustrations, first by Moi and then by Kibaki (Lumumba 2008:12-13). Tobiko was confirmed to the post, despite failing to clear his name of allegations of corruption and impropriety levelled against him in the course of vetting. His appointment was indicative of the systemic impediments against reform in Kenya's body politic. MPs in the coalition government unanimously endorsed his appointment. His inability to successfully prosecute senior government officials implicated in grand corruption hamper the fight against malfeasance and abuse of public office. Rather than the Director of 
Public Prosecutions being integral to entrenchment of the rule of law, he became an impediment to constitutionalism.

Kenya's ancien régime has had some of its members, such as Uhuru Kenyatta and William Ruto, implicated in crimes against humanity and "criminalisation of the state" (Bayart, Ellis and Hibou 1999), pervasive in other polities in Africa. Until issues raised and recommendations contained in official reports, specifically the Truth Justice and Reconciliation Commission (TJRC), are acted upon, Kenya's political stability will remain precarious (TJRC of Kenya 2013). There is no political will to implement these recommendations, because it is in the best political and economic interest of Kenyatta-Moi-Kibaki kleptocratic axis and their supporters that truth telling is supressed (Daily Nation 2010c; Daily Nation 2010d; Daily Nation 2010a). This axis is implicated in Kenya's postcolonial turmoil and so is intent on frustrating the address of historical injustices; an attempt that tries to institutionalise amnesia and derail the implementation of the Constitution. Reform threatens to overhaul the status quo that accords privileges to plutocrats and their cronies, while condemning the majority of Kenyans to poverty and denies them public goods.

The paradox of Kenya's reform process is that the most reactionary section of Kenya's politicians, who exploit their control of the state to illicitly accumulate wealth and grab public land, who have been implicated in gross human rights violations, such as extrajudicial killings and incitement to ethnic violence, and faced charges for crimes against humanity at the ICC, are expected to provide leadership in the implementation of the Constitution (Republic of Kenya 2004; Republic of Kenya 1999). This is the conundrum facing Kenya's reform process.

In November 2013, Ipsos Synovate conducted a survey on what Kenyans thought to be the two achievements of the Jubilee Government that far. Of those polled, $2 \%$ were of the view that the government supported devolution, while $1 \%$ thought the government was on the right track with regard to the implementation of the Constitution. In a follow up survey in February 2014, results relating to the two issues of devolution and implementation of the Constitution remained the same. Even among government, $2 \%$ from both sides of the political divide, both Jubilee supporters and the opposition CORD supporters, believed that the government supported devolution, while $1 \%$ believed that the government supported the implementation of the Constitution (Ipsos Synovate 2014). Subsequent surveys have seen most Kenyans lose confidence in the Jubilee Government over allegations of runaway corruption, insecurity and a high cost of living. Thus, the majority of Kenyans hold the view that there is no political will from Kenyatta prerequisite to the rolling out of devolved government units within the 2010 constitutional framework. The 2014 survey was crucial, because it was conducted early during his regime. As such, it was a barometer of Kenyatta's lack of commitment to reform. The window of reform is often narrow and if a newly elected president does not stamp his/her authority from the start, it proves 
much more difficult to clean up the state later. The survey showed that the old order, socialised in "Big Man politics" of impunity, is resistant to reform.

Despite the new constitutional dispensation, the legacy of a subservient judiciary that panders to the interests of the executive seems to be intact (Shilaho 2013:93-102). The case involving the election date was the first litmus test of the judiciary under the 2010 Constitution. The verdict that moved elections back to 2013 from 2012 gave politicians and bureaucrats a hint that the Constitution is fair game that they can manipulate and cavalierly amend as was the case with the Lancaster House Constitution. Succession politics and the ICC cases rendered the 2013 elections dicey. The ruling in favour of Kenyatta and Ruto effectively dealt a blow to Chapter 6 of the Constitution that attempted to place primacy on integrity in Kenya's body politic. Vetting of judges and magistrates, to weed the judiciary of compromised elements, has come under resistance by old order judges. The declaration of Kenyatta as presidential winner amidst allegations of irregularities diminished confidence in the judiciary by a section of Kenyans.

\section{CONCLUSION}

The article primarily focuses on Kenya's winding and torturous constitutional reform path. Arbitrary, but deliberate amendments made to the Lancaster House Constitution of 1963 were partly to blame for Kenya's socio-economic and political challenges. The amendments removed the doctrine of separation of powers and compromised the independence of oversight institutions critical to a functioning democracy. As such, the Constitution served the interests of the president and other ethno-regional "Big Men". Jomo Kenyatta and Daniel Arap Moi tampered fundamentally with it, ensuring that multiparty democracy could not challenge their despotic single party régimes. Mwai Kibaki and Uhuru Kenyatta exhibited impunity, breaching the Constitution even after the promulgation of the 2010 Constitution. Uhuru Kenyatta attempted to claw back on democratic gains by chipping away at the Constitution, interfering with the separation of powers in an attempt to create a powerful president, and watering down the bill of rights. This political behaviour is reminiscent of the dictatorial one party state and, unless halted by the collective efforts of civil society and the opposition, could wipe out democratic gains and plunge the country into a crisis, because it erodes the rule of law that is supposed to be the anchorage for political stability.

Noteworthy is that institutionalised impunity in Kenya's body politic diminishes the functioning of the state. The failure by the country to undergo reform after the 2002 elections set the stage for the polarising 2005 referendum on a draft Constitution, and the controversial and destabilising 2007 elections. As an opposition politician, Kibaki and his supporters opportunistically called for reform, but, once in power, reform became anathema characteristic of the self- 
professed democrats of multiparty politics in Africa who are socialised in personal rule (Hyden 2006:104).

Ethnicity has been entrenched in the country's body politic because of the preponderance of opportunism and provincialism among politicians, the judiciary, and other statutory bodies. Kenya remains ethnically bifurcated, as were evidenced during the 2005 and 2010 Constitution referenda, the 2007 elections, the 2013 elections and the aftermath. The inability of Kenya's politicians and other local political role players to envision a Kenya in which the collective interests of the nation count, reinforces friction and feeds into recurrent ethnic conflict. Much as the 2010 Constitution was expected to address this deleterious political behaviour, a constitution can only be as good as the government that is supposed to implement it.

Kenya's socio-economic and political renaissance requires that Kenya's politicians act in accordance with the Constitution. This is a challenge, because the Constitution is often disregarded owing to personal rule and the propensity to conduct the business of governance in an informal, rather than a formal and institutionalised manner. Hyden identifies personal rule as inimical to the African polity, since the logic that guides most African rulers is political advantage for the ruler and his supporters, rather than how to manage effectively the economy for the wellbeing of the citizenry (Hyden 2006). Kenya's Constitution reform is held hostage by the insular schemes of the political elite. The implementation of the 2010 Constitution was meant to be an opportunity through which Kenyans could negotiate on how to govern themselves, but it has turned out to be yet another battleground and an incubator for political intrigues and violence.

Kenya has made strides towards reform in the aftermath of the 2007 post-election violence. This is reflected through the realisation of the 2010 Constitution, a milestone in the country's post-colonial history. Nevertheless, attitudinal change among politicians and within the judiciary and statutory bodies is missing. Elections are still controversial, polarising and anxiety inducing exercises, rather than an opportunity for Kenyans to genuinely exercise their right in participatory democracy. This reinforces a culture of impunity and underscores the fact that Kenya's body politic is in need of constitutionalism. Kleptocrats, who have benefited from a one party autocracy, are still in charge of the state. Their allies and those masquerading as forces for change while biding time in the opposition, waiting for their "turn to eat" - a reference to the exploitation of power for corrupt enrichment - cannot be expected to facilitate Kenya's transition and transformation. The fear of accountability, and even of losing ill-gotten wealth, compels these people to block reform. Kenya is becoming more ethnically polarised under multiparty politics that was expected to herald a new political system, based on transparency and accountability. 


\section{LIST OF SOURCES}

Ajulu, R 2002. "Politicised ethnicity, competitive politics and conflict", African Studies 61(1):251-268, https://doi.org/10.1080/0002018022000032947

Ajulu, R 2008. "Kenya's 2007 elections: Derailing democracy through ethnoregional violence", Journal of African Elections Special Issue on Kenya 7(2):33-51.

Al Jazeera 2014. "Mombasa bloodshed and alleged police impunity. Rights groups demand justice after spate of alleged extrajudicial killings in Kenya's violence plagued coastal city", 4 November, <http://www.aljazeera.com/ indepth/features/2014/11/mombasa-bloodshed-alleged-police-impunity2014113111144512173.html>, accessed 9 December 2015.

Anderson, D and E Lochery 2008. "Violence and exodus in Kenya's Rift Valley, 2008: Predictable and preventable?", Journal of Eastern African Studies 2(2):328-343, https://doi.org/10.1080/17531050802095536

Atieno-Odhiambo, E 2002. "Hegemonic enterprises and instrumentalities of survival: Ethnicity and democracy in Kenya", African Studies 61(2):223-249, https://doi.org/10.1080/0002018022000032938a

Baregu, M 2010. "The legitimacy crisis and the resource of military coups in Africa: The limits of democratisation". In: K Matlosa, G Khadiagala and V Shale (eds), When elephants fight: Preventing and resolving election-related conflicts in Africa. Johannesburg: EISA.

Barkan, JD and F Matiangi 2009. "Kenya's tortuous path to successful legislative development". In: JD Barkan (ed.), Legislative power in emerging African powers. Boulder, London: Lynne Rienner Publishers.

Bayart, J 1993. The state in Africa: The politics of the belly. London: Longman.

Bayart, J-F, S Ellis and B Hibou 1999. The criminalisation of the state in Africa. Oxford: James Currey.

BBC News Africa 2011. "Kenya's MPs ordered to pay higher taxes", 21 June, <http:// www.bbc.co.uk/news/world-africa-13857480>, accessed 11 November 2015.

Berman, B 1998. "Ethnicity, patronage and the African state: The politics of uncivil nationalism", African Affairs 97(388):305-341, https://doi.org/10.1093/ oxfordjournals.afraf.a007947 
Branch, D and N Cheeseman 2009. "Democratization, sequencing, and state failure in Africa: Lessons from Kenya", African Affairs 108(430):1-26, https://doi. org/10.1093/afraf/adn065

Business Daily 2014a. "UK exposes corruption ring at Kenya poll agency", 17 November, <http://www.businessdailyafrica.com/UK-court-exposes-briberyring-in-Kenya-poll-agency/-/539546/2525946/-/530fouz/-/index.htm>, accessed 2 December 2015.

Business Daily 2014b. "How UK sleuths unearthed Kenya 'Chicken gate' scandal", 18 November, <http://www.businessdailyafrica.com/How-UK-sleuthsunearthed-Kenya scandal/-/539546/2527142/-/12a1fcrz/-/index.html>, accessed 2 December 2015.

CapitalNews 2014. “Men in Black' disrupt ODM elections”, 28 February, <http:// www.capitalfm.co.ke/news/2014/02/men-in-black-disrupt-odm-elections/>, accessed 9 December 2015.

Cheeseman, N 2008. "The Kenyan elections of 2007: An introduction", Journal of Eastern African Studies 2(2):166-184, https://doi.org/10.1080/17531050802058286

Cheeseman, N and B Tendi 2010. "Power-sharing in comparative perspective: The dynamics of 'unity government' in Kenya and Zimbabwe", Journal of Modern African Studies 48(2):203-229, https://doi.org/10.1017/S0022278X10000224

Daily Nation 2010a. "Public walkout on TJRC meeting", 30 January, <http:// www.nation.co.ke/News/-/1056/852648/-/item/1/-/6kxl9y/-/index.html>, accessed 4 November 2015.

Daily Nation 2010b. "Obama, Annan laud Kenyans over new Constitution", 6 August, <http://www.nation.co.ke/Kenya\%20Referendum/Obama,\%20Annan\%20 laud\%20Kenyans\%20over\%20new\%20Constitution/-/926046/971994/-/qte3tk/-/ index.html>, accessed 29 October 2013.

Daily Nation 2010c. "Truth commission fights for survival", 4 September, <http:// www.nation.co.ke/News/Truth\%20team\%20fights\%20for\%20survival\%20//1056/1003914/-/item/1/-/kmac47/-/index.html>, accessed 30 October 2015.

Daily Nation 2010d. "Truth team now wants Kiplagat suspended", 30 October, <http://www.nation.co.ke/News/Truth $\% 20$ team $\% 20$ now $\% 20$ wants $\% 20$ Kiplagat\%20suspended\%20/-/1056/1043690/-/v6i6x1z/-/index.html>, accessed 29 October 2010. 
Daily Nation 2012a. "Blunders in laws for the new Constitution", 17 February, <http://www.nation.co.ke/News/politics/Blunders+in+laws+for+new+Constituti on+/-/1064/1329108/-/item/0/-/195tjdz/-/index.html>, accessed 17 November 2015.

Daily Nation 2012b. "Shabbir: MPs were bribed to save CBK boss", 10 March, <http://www.nation.co.ke/News/politics/Shabbir+MPs+were+bribed+to+save+CB K+boss+/-/1064/1363750/-/l715am/-/index.html>, accessed 11 November 2015.

Daily Nation 2015. "Revealed. How ethnic groups share public jobs", 5 January, <http://www.nation.co.ke/news/Revealed-How-ethnic-groups-share-public-jobs//1056/2581834/-/to0s7bz/-/index.html>, accessed 11 January 2015.

Frohnen, BP 2011. “Is constitutionalism liberal?”, Campbell Law Review 33(3).

Ghai, Y 2008. "Devolution: Restructuring the Kenyan state", Journal of East African Studies 2(2):211-226, https://doi.org/10.1080/17531050802058336

Henkin, L 1998. "Elements of constitutionalism”, The Review 60:11-22.

Human Rights Watch (HRW) 2011. "Turning pebbles': Evading accountability for post- election violence in Kenya", <http://www.hrw.org/sites/default/files/reports/ kenya1211webwcover_0.pdf>, accessed 1 December 2015.

HRW 2013. "High stakes and the 2013 elections in Kenya", <http://www.hrw.org/ sites/default/files/reports/kenya0213webwcover.pdf>, accessed 14 December 2015.

HRW 2014. "Kenya: Killings disappearances by Anti-Terror Police: Donors should suspend support for abusive units", 18 August, <https://www.hrw.org/ news/2014/08/18/kenya-killings-disappearances-anti-terror-police>, accessed 9 December 2015.

Hyden, G 2006. African politics in comparative perspective. New York: Cambridge University Press.

Ihonvbere, J 2003a. "A balance sheet of Africa's transition to democratic governance". In: J Mbaku and J Ihonvbere (eds), The transition to democratic governance in Africa: The continuing struggle. London: Praeger Publishers.

Ihonvbere, J 2003b. "Constitutions without constitutionalism? Towards a new doctrine of democratization in Africa". In: J Mbaku and J Ihonvbere (eds), The transition to democratic governance in Africa: The continuing struggle. London: Praeger Publishers.

Institute for War and Peace Reporting (IWPR) 2014. "Public confidence in Kenya's judiciary plummets, recent dismissals further increase dissatisfaction 
with national justice system", 17 April, <https://iwpr.net/global-voices/publicconfidence-kenyas-judiciary-plummets>, accessed 14 December 2015.

Ipsos Synovate 2014. "KE Ipsos-PEC-Poll-Report-One-Year-into-the-JubileeGovernment- Just-What-Are-Kenyans-Realities", <http://www.ipsos.co.ke/ home/index.php/ downloads>, accessed 23 November 2015.

Kautz, S 1999. "Liberty, justice and the rule of law", Yale Journal of Law and the Humanities 11 Yale, J. L \& Human:435, 440.

Kenya Human Rights Commission (KHRC) 2011. "Lest we forget: The faces of impunity in Kenya, Nairobi”, <www.khrc.or.ke>, accessed 9 November 2015.

Kenya National Commission on Human Rights (KNCHR) 2008. "The cry of blood". Report of extra-judicial killings and disappearances", <http://www. marsgroupkenya.org/pdfs/2009/03/KNCHR_crimes-against-humanity-extrajudicial-killings-by-kenya-police- exposed.pdf>, accessed 9 November 2015.

Khadiagala, G 2008. "Forty days and nights of peacemaking in Kenya", Journal of African Elections Special Issue: Kenya 7(2):4-32.

Khadiagala, G 2010. "Political movements and coalition politics in Kenya: Entrenching ethnicity", South African Journal of International Affairs 17(1):65-84, https://doi.org/10.1080/10220461003763858

Leys, C 1975. Underdevelopment in Kenya: The political economy of colonialism. London: Heinemann.

Lumumba, P 2008. Kenya's quest for a Constitution: The postponed promise. Nairobi: The Jomo Kenyatta Foundation.

Mafeje, A 1971. "The ideology of tribalism", The Journal of Modern African Studies 9(2):253-261, https://doi.org/10.1017/S0022278X00024927

Mazrui, A 2001. "Constitutional change and cultural engineering: Africa's search for new directions". In: J Oloka-Onyango (ed.), Constitutionalism in Africa: Creating opportunities, facing challenges. Kampala: Fountain Publishers.

Mbaku, J 2003. "Constitutionalism and transition to democratic governance in Africa". In: J Mbaku and J Ihonvbere (eds) The transition to democratic governance in Africa: The continuing struggle. London: Praeger Publishers.

Mueller, S 2008. "The political economy of Kenya's crisis", Journal of Eastern African Studies 2(2):185-210, https://doi.org/10.1080/17531050802058302 
Muigai, G 1996. "Legal constitutional reforms to facilitate multi-party democracy: The case of Kenya". In: J Oloka-Onyango, K Kibwana, and CM Peter (eds), Law and the struggle for democracy in East Africa. Nairobi: Claripress.

Murungi, K 2000. In the mud of politics. Nairobi: Acacia Stantex Publishers.

Mutua, M 2009. Kenya's quest for democracy: Taming the Leviathan. London: Lynne Rienner Publishing.

Mutunga, W 1996. "Building popular democracy in Africa: Lessons from Kenya". In: J Oloka-Onyango, K Kibwana and CM Peter (eds), Law and the struggle for democracy in East Africa. Nairobi, Claripress.

Nyinguro, $\mathrm{P}$ and E Otenyo E 2007. "Social movements and democratic transitions in Kenya", Journal of Asian and African Studies 42(1):5-24, <http://jas.sagepub. com/content/42/1/5>, accessed 22 October 2015.

Ochieng', W 1995. "Structural and political changes". In: BA Ogot and WR Ochieng' (eds), Decolonization and independence in Kenya. London: James Currey.

Oloka-Onyango, J 2001. "Introduction constitutionalism in Africa: Yesterday, today and tomorrow". In: J Oloka-Onyango (ed.), Constitutionalism in Africa: Creating opportunities, facing challenges. Kampala: Fountain Publishers.

Organisation Mondiale Contre la Torture (OMCT, World Organisation Against Torture) 2008. "The lie of the land addressing the economic social and cultural root causes of torture and other forms of violence in Kenya", <www.omct.org>, accessed 5 October 2015.

Republic of Kenya 1992. Report of Parliamentary Select Committee to investigate ethnic clashes in Western and other parts of Kenya: "Kiliku Commission". Nairobi: Government Printer.

Republic of Kenya 1999. Report of the Judicial Commission appointed to inquire into tribal clashes in Kenya: "Akiwumi Commission". Nairobi: Government Printer.

Republic of Kenya 2004. Report of the Commission of Inquiry into the illegal/ irregular allocation of land. Nairobi: Government Printer.

Republic of Kenya 2008a. Report of the Independent Review Commission on the general elections held on 27th December or "the Kriegler Commission". Nairobi: Government Printer.

Republic of Kenya 2008b. Commission of Inquiry into Post-Election Violence (CIPEV) or "the Waki Commission". Nairobi: Government Printer, <http://www. dialoguekenya. org/docs/PEV\%20Report.pdf>, accessed 10 November 2015. 
Republic of Kenya 2010. The Proposed Constitution of Kenya. The Final Report of the TJRC of Kenya, 2013. Nairobi: Government Printer, <http://digitalcommons. law. seattleu.edu/tjrc/>, accessed 11 December 2015.

Republic of Kenya 2014. Security Laws (Amendment) Bill, 2014, <http:// www.hapakenya.com/wp-content/uploads/2014/12/THE-SECURITY-LAWSAMENDMENT-BILL-2014.pdf>, accessed 30 December 2015.

Shilaho, W 2012. The role of ethnicity in Kenya's transition from single party to political pluralism (1992-2007). PhD, University of the Witwatersrand, Johannesburg.

Shilaho, W 2013. "Old wine in new skins: 2013 elections and the triumph of the Ancien Regime", Journal of African Elections Special Edition (The evolving role of elections in Africa) 12(3):77-112.

Shilaho, W 2014. 'I do not know who won the elections': How not to conduct elections and Kenya's democratic reversals", Politeia 33(3):44-67.

Shilaho, W 2015. "Third time lucky? Devolution and state restructure under Kenya's 2010 Constitutional dispensation". In: LA Carl, JO Fashagba and ER McMahon (eds), Africa state governance subnational politics and national power. New York: Palgrave Macmillan, pp. 147-177, https://doi.org/10.1057/9781137523341_6

Standard Digital 2014a. "Uhuru Kenyatta, William Ruto strongholds hog half of public jobs", 18 January, <http://www.standardmedia.co.ke/?articlelD=200 0102571\&story_title=Kenya-uhuru-ruto-strongholds-hog-half-of-public-jobs >, accesssed 11 December 2015.

Standard Digital 2014b. "Report lists counties with highest poverty", 30 April, <http:// www.standardmedia.co.ke/?articlelD=2000110595>, accessed 2 December 2015.

Standard Digital 2014c. "Independent Electoral and Boundaries Commission 'knew' voters register was faulty ahead of last elections", 21 September, <http:// www.standardmedia. co.ke/?articlelD=2000135633\&story_title=iebc-knewvoters-register-was-faulty-ahead-of-last-elections>, accessed 2 December 2015.

Standard Digital 2015. "Prosecute rogue MPs after shock theft of money in parliament", 7 December, <http://www.standardmedia.co.ke/article/2000184616/ prosecute-rogue-mps-after-shock-theft-of-money-in-parliament/>, accessed 7 December 2015.

The Guardian 2013. "Kenyan court clears way for Uhuru Kenyatta to run in election", 15 February, <http://www.guardian.co.uk/world/2013/feb/15/kenyancourt-clears-uhuru-kenyatta-election>, accessed 21 November 2015. 
The Star 2015a. "POLL: Most Kenyans believe that corruption suspects will not be convicted", 5 December, <http://www.the-star.co.ke/news/poll-most-kenyansbelieve-corruption-suspects-will-not-be-convicted>, accessed 7 December 2015.

The Star 2015b. "I do not fear arrest or jail, says Raila", 14 December, <http://www. the-star.co.ke/news/2015/12/14/i-dont-fear-arrest-or-jail-says-raila_c1260152>, accessed 14 December 2015.

Wanjala, S 1996. "Presidentialism, ethnicity, militarism and democracy in Africa: The Kenyan example”. In: J Oloka-Onyango, K Kibwana and CM Peter (eds), Law and the struggle for democracy in East Africa. Nairobi: Claripress. 